\title{
Diversity, Utilization and Management of Medicinal Plants in Baitadi and Darchula Districts, Far West Nepal
}

\author{
Ripu M. Kunwar ${ }^{1}$, Chotte L. Chowdhary \\ \& Rainer W. Bussmann ${ }^{3}$
}

\begin{abstract}
As in other districts of Nepal, medicinal plants have played a significant role in the life of local people of Baitadi and Darchula districts by providing products for trade, subsistence and traditional therapies. Present study analyzed the pharmacological activities of the species which had the highest informant consensus factor. The use of Asparagus racemosus as galactogogue with consensus factor 0.97, Berberis asiatica for eye troubles with 1.0, Cordyceps sinensis as tonic and longevity with 0.97, Curculigo orchoides as tonic and aphrodisiac with 0.96, Nardostachya grandiflora for epilepsy with 0.97 and Phyllanthus emblica as diuretic with 0.97 possessed the highest consensus factors and greatest affinity to the Ayurveda and phytochemical findings. Phytochemical screening and validity assessments of the medicinal plant widely used in traditional therapies are worthwhile. The findings with the maximum affinity of informant consensus factors and phyto-chemical validations provide the potential to identify uhich plants are most likely to be useful in the treatment of diseases.
\end{abstract}

Key Words: Medicinal plants, Ethno-medicine, Informant consent factor(ICF), Phyto-chemical validation, West himalaya

\section{Introduction}

It has been estimated that the Himalayan region harbors about 12,000 species of medicinal and aromatic plants, supporting the livelihood of about 600 million people living in the area (Pie Shengji 2001). The flora of the Nepal Himalaya contains 10,167 plant species, of which over 7,000 are flowering plants and over 1,600 species are medicinal and aromatic herbs. The herbs, representing about $25 \%$ of the total country's vascular flora, are used under different traditional systems including the Ayurveda, Homeopathic, Home herbal (folklore) and Amchi (traditional Tibetan medicine) medicinal systems (Bhattarai 1997). Thirty percent medicinal plant species of the country occur in the western part of the country (Manandhar 1998) and about $50 \%$ of the plants used as ethno-medicine in Nepal Himalaya (Kunwar et al. 2008) have been documented. The management of medicinal and aromatic plants and knowledge of utilization of the resources therefore is of great importance and it can be promoted by considering and documenting the diversity of the medicinal plant resources and their indigenous knowledge of utilization (Kunwar et al. 2006).

\footnotetext{
.Centre for Biology Conservation, P.O. Box 19225, Kathmandu, Nepal, rkunwar@gmail.com

2 Canadian Center for International Studies and Cooperation (CECI), kathmandu, Nepal

3 William L. Brown Center, Missouri Botanical Garden, St. Louis, USA.
} 


\section{Study Area}

As there is varied topography, bioclimate and forest products (Devkota \& Karmacharya 2003), both the Baitadi and Darchulsa districts possess a large variety of non-timber forest products and they have been collected since ancient past for domestic use, particularly for home herbal healing. Baitadi district ranges from $390 \mathrm{~m}$ to $2950 \mathrm{~m}$ altitude, $29^{\circ} 22^{\prime}-29^{\circ} 57^{\prime} \mathrm{N}$ latitude, and $80^{\circ} 5^{\prime}-80^{\circ} 57^{\prime} \mathrm{E}$ longitude, and Darchula district stretches from $357 \mathrm{~m}$ to $7132 \mathrm{~m}$ altitude, $29^{\circ} 26^{\prime}-30^{\circ} 15^{\prime} \mathrm{N}$ latitude and $80^{\circ} 22^{\prime}-81^{\circ} 90^{\prime} \mathrm{E}$ longitude. Community forests and their user groups, other government managed forests and NTFP collectors, traders and producers of Siddeswor VDC of Baitadi district and Khar and Dumling VDCs of Darchula districts were selected as study site and respondents for this study.

Because of the diversity and richness of the products in study area, some sites were community managed and some sites were government managed for better management. There is a belief of better management systems in community managed areas. Now, the forest lands lying at the vicinity of the settlement areas have been administered by local community and used the resources under indigenous management systems and customs and five years operational plans as community forests. Community forest user groups run under users' forest operational plan and constitution and National Forest Act $(1961,1993)$ and they are recognized as an independent institution.

\section{Materials and Methods}

Field visits were carried out in January-February 2007 and March-April 2008 and field observations were analyzed to evaluate the diversity, uses and management of medicinal plant resources. Group discussions, field observations, questionnaire surveys, cross checking, and key informant surveys were major tools as participatory appraisal. Group discussions were held as informal interactions, meetings, formal discussions, etc. and they were organized within community forest user groups.

Traders, collectors, traditional healers and producers were individually asked. A total of 174 respondents including 122 men and 52 women were asked for data collection. All the traditional healers and village/district NTFP traders of the study area were consulted. Collectors were selected randomly with keeping diversity in gender, ethnicity and well being. Checklists were made for crosschecking and key informant survey. In total, the respondents for surveys were carefully selected based on gender, caste, occupation, ethnicity and well being. The information was further validated by common response and considered as insignificant for single response.

\section{Results and Discussion}

\section{Diversity}

The present study got an account of 76 plant species having medicinal values and properties. Among them 47 were indigenously used as ethno-medicine. Among the ethno-medicinal plants, 29 species were only from Darchula district, 19 were only from Baitadi district and 19 species were common to both districts. The high altitude medicinal herbs (Cordyceps sinensis, 
Dactylorhiza hatagirea, Morchella conica, Nardostachys grandiflora, Neopicrorhiza scrophulariflora, etc.) were reported from Darchula district while the tropical and temperate medicinal plants (Acorus calamus, Astilbe rivularis, Berberis asiatica, Centella asiatica, Moringa oleifera, etc.) were reported from Baitadi district. The common medicinal plants were Asparagus racemosus, Bergenia ciliata, Juglans regia, Paris polyphylla, Phyllanthus emblica, Swertia chirayita, Zanthoxylum armatum, etc.

\section{Utilization and management}

Table 1 shows the number of medicinal plant species used for each of the usage categories with their informant consensus factor. To take the level of diseases category analysis, an informant consent factor (ICF) was calculated following Trotter \& Logan (1986). Result showed the high level of consensus where the total 47 plant species revealed the data range 0.86-1.00 but the present study analyzed only the species possessed informant consensus factor 0.95 and more. There were only 13 species with their informant consensus factor 0.95 or more, therefore the discussion of the study confined only on those species.

All the informants were consent upon the usage of Berberis asiatica for eye troubles and Cordyceps sinensis for memory longevity. It was also supported by the use of $B$. asiatica for eye infection in Tamang ethnic groups with possessing ICF 0.92 from central Nepal Himalaya (Yadav 2008). All the species possessing the highest consensus factor $(0.97-1.00)$ revealed the affinity to the Ayurveda and phytochemical findings. Use of Asparagus racemosus as galactogogue (0.97), Berberis asiatica for eye troubles (1.0), Cordyceps sinensis as tonic and longevity (0.97), Curculigo orchoides as tonic and aphrodisiac (0.96), Nardostachya grandiflora for epilepsy (0.97) and Phyllanthus emblica as diuretic (0.97) possessed the highest consensus factor and they were concurred with the phyto-chemical findings. High consensus factor means the usage of these species are well known in study area. It can be excerpted from the findings that the species with the highest consensus factor (more than 0.97 in this study) are in line with the phyto-chemical validations and the species with the least consensus factor are misused during course of social-cultural and economical transformation. The species with the highest consensus factor and strong resemblances with phytochemical findings are potential for the investigation of phyto-chemistry and pharmacology.

However, with increasing use of traditional therapies, a verification of efficacy by western scientific means would be interesting, because the traditional health system adopt customized and multi-pronged strategies in treatment involving drug, diet and therapy. Results of the present study suggest a fairly good correlation between traditional therapeutic use and the in vitro phyto-chemical activity because the findings showed only about $50 \%$ affinity. It shows that the home herbal remedy is an independent health care system of Nepal Himalaya which is indigenous and influenced by the Ayurveda. These results corroborate the importance of ethno-pharmacological surveys for screening plants as a potential source for bioactive compounds. Hence these could result in discovery of novel antimicrobial agents. The unlike uses of the species after thorough scrutinization under different health care systems and comparisons pose research scopes and such uses would better to be researched and or 
alchemized. However, the changing life, perceptions, social transformation and acculturation result the indigenous knowledge gradual denudation.

Table 1: Medicinal plants, their usage and informant consensus factor (ICF) value

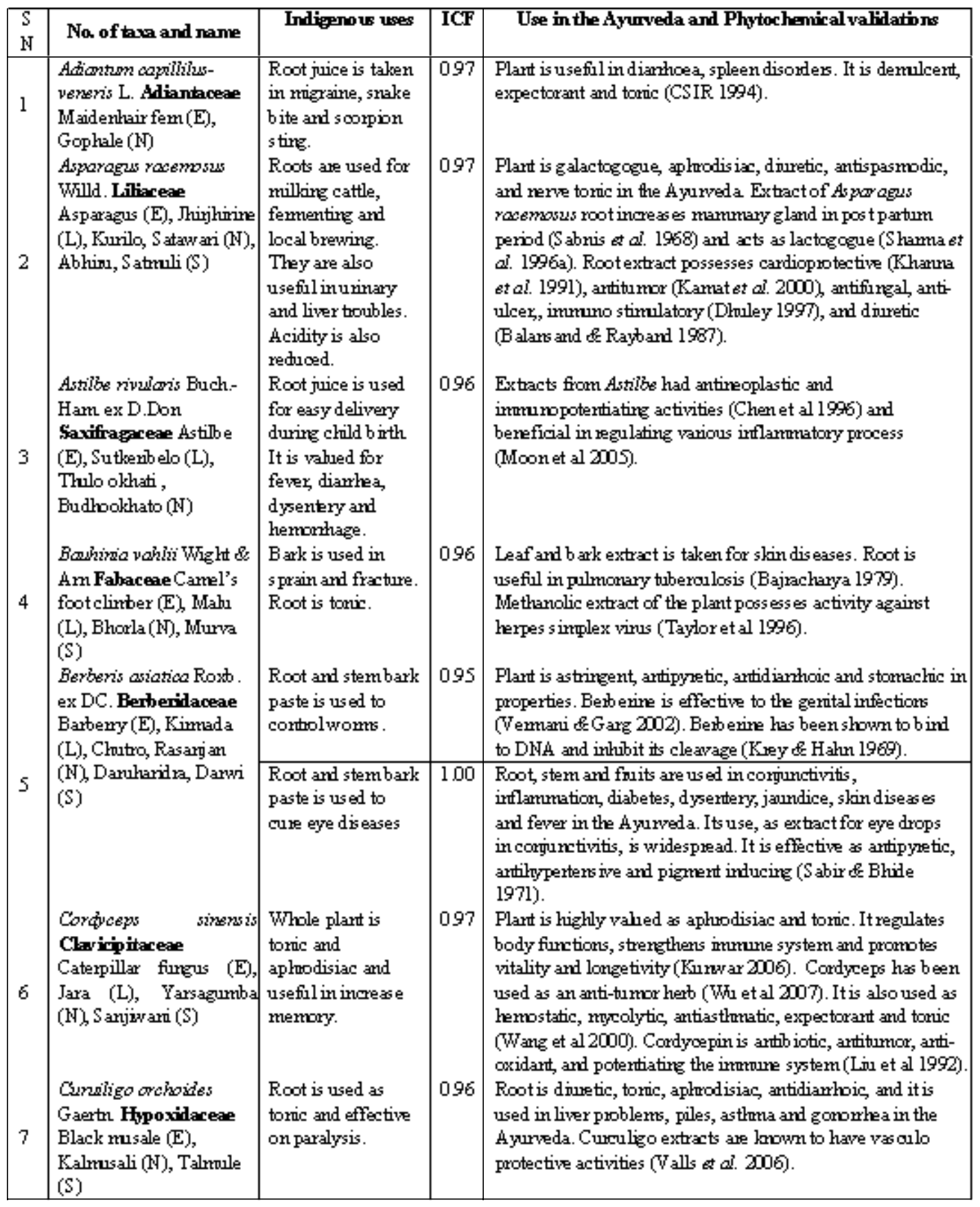




\begin{tabular}{|c|c|c|c|c|}
\hline 8 & $\begin{array}{l}\text { Curcuma zeodoria Rosc. } \\
\text { Zingheraceae Zeodory, } \\
\text { Tumeric (E), Sathi, } \\
\text { Kachor (L) Haldi (N) }\end{array}$ & $\begin{array}{l}\text { Rhizome is used in } \\
\text { paralysis. }\end{array}$ & 096 & $\begin{array}{l}\text { Hydroalcoholic extract, fractions, s pecially } \\
\text { dichloromethane, and a pure compound of Curcum } \\
\text { rumos demoted as curoumerol, exhub ited potent and dose } \\
\text { related amakesic activity (Navano et al } 2002 \text { ). }\end{array}$ \\
\hline 9 & $\begin{array}{l}\text { Jatropha aurcas L. } \\
\text { Euphomiaceae Arim, } \\
\text { Physic rout (E), Inra (L), } \\
\text { Sajnam (N), Vyaghra } \\
\text { eranda(S) }\end{array}$ & $\begin{array}{l}\text { Seed oil is applied } \\
\text { on arthritis and } \\
\text { boils. }\end{array}$ & 096 & $\begin{array}{l}\text { Seed and latex are a tingent and purgative in properties and } \\
\text { are employed in scabies, eczema, irflammations and wounds } \\
\text { Root extract is artidianhoel. Root paste can be used as anti- } \\
\text { irflammatory (Mujumdar \& Misar 2004). }\end{array}$ \\
\hline 10 & $\begin{array}{l}\text { Nardostochys grandiflora } \\
\text { DC. Valerianaceae } \\
\text { Spikenard, Musk root } \\
\text { (E), Bloulte (L), Jatamansi } \\
\text { (N), Jatarmas i, } \\
\text { Gandhamasi(S) }\end{array}$ & $\begin{array}{l}\text { Root and rhizome } \\
\text { is useful in } \\
\text { epilepsy and } \\
\text { mertalweakness. } \\
\text { Oil is useful in } \\
\text { head ache. }\end{array}$ & 097 & 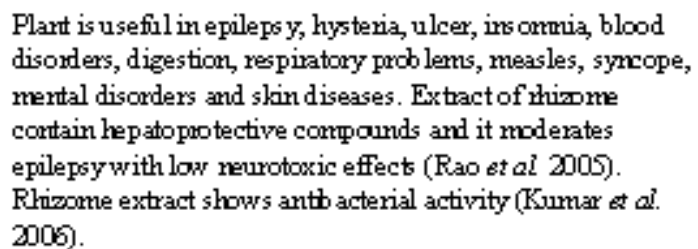 \\
\hline 11 & $\begin{array}{l}\text { Phyllonths emblica L. } \\
\text { Euphomiaceae. } \\
\text { Goosebery (E), Aurla } \\
\text { (L), Amala, Rikhyy (N), } \\
\text { Dhatri, Aadiphala (S) }\end{array}$ & $\begin{array}{l}\text { Fresh fnits are } \\
\text { used as diuretic } \\
\text { and laxative. }\end{array}$ & 097 & 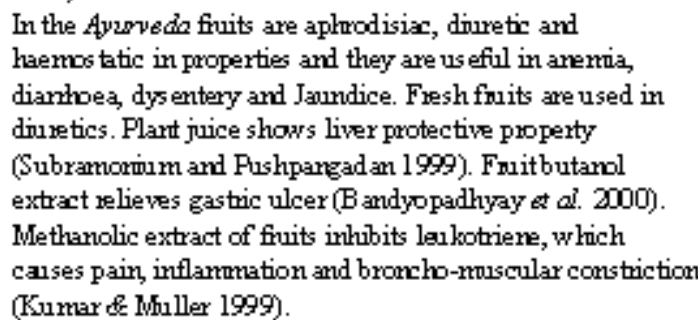 \\
\hline 12 & $\begin{array}{l}\text { Sophora mollis (Grah ex } \\
\text { Royle) Fabaceae } \\
\text { Himalayan laburum(E) } \\
\text { Clourmiado (N) }\end{array}$ & $\begin{array}{l}\text { Root paste is } \\
\text { considered in oold } \\
\text { and theumatism. }\end{array}$ & 096 & $\begin{array}{l}\text { Flowes are diuretios, and us efil in humbago and kidney } \\
\text { problems. Seed is good in eye troub bs (Kirtikar and Baan } \\
\text { 1981). Root extact promotes hair growth (CSIR 1994). It is } \\
\text { antiinflammatory, and antotumorous and inlubits liver } \\
\text { fib rosis (Zhang et al 2001). }\end{array}$ \\
\hline 13 & $\begin{array}{l}\text { Untica doica L. } \\
\text { Urticaceae S tinging } \\
\text { neetle (E), Sis ru (H), } \\
\text { Agnidamani(S) }\end{array}$ & $\begin{array}{l}\text { Wood is used for } \\
\text { fracture and } \\
\text { sprains. Leaf is } \\
\text { used as vegetible. }\end{array}$ & 096 & 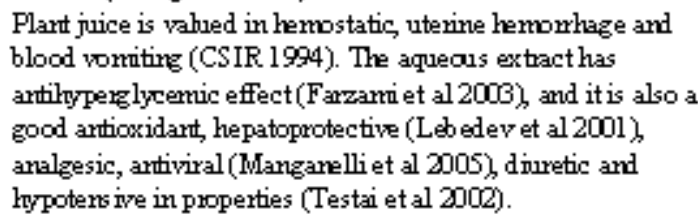 \\
\hline
\end{tabular}

$\mathrm{E}=$ English, $\mathrm{L}=$ Local, $\mathrm{N}=$ Nepali and $\mathrm{S}=$ Sanskrit

Medicinal plants were assumed to be a free commodity in Nepal and were mainly collected from wild since ancient past, which can make a significant contribution to the livelihoods, health care and income for those people who residing forest and pasture fringes and in rural areas (Kunwar 2002). Medicinal plants were collected as food, vegetable, and medicine for both domestic and commercial purposes. Some medicinal plants are used for home herbal remedy whilst the traditional healers (Baidhyas) used the species as major ingredients for their medicinal preparations (CECI 2006). However, the commercial collections of the species, started about a decade ago in the study area (CIRRUS 2008), are already threatening the populations of many species.

As a result of human population growth, habitat destruction and increasing commercial exploitation, pressure upon the existing plant resources is ever increasing. The number of individuals involved in collection, production and marketing of medicinal plants has noticeably increased in the study area (16.16\% in comparison with 2007 data) due to a high growth 
global market of phytomedicines (Kunwar 2007). The global market of medicinal products (herbal products including medicinal, health supplements, and herbal beauty and toiletry) is over USD 60 billion and grows at the rate of 7\% increment per annum (Nagpal \& Karki 2004).

The harvesting knowledge level varied in each collectors group and depended on a species and its phenology. Most of the high value medicinal herbs such as Cordyceps (Yarchagunbu), Morchella (Guchhi), Zanthoxylum (Timur), etc. were collected with paying greater attention. Irrational (in terms of time, productivity and quality) collections have made the species namely Nardostachys grandiflora, Neopicrorhiza scrophulariflora, Astilbe rivularis, Dactylorhiza hatagirea and Juglans regia threatened.

\section{Conclusion}

As in other indigenous communities of the world, the communities of the Baitadi and Darchula districts are experiencing great changes in their way of life. However, medicinal plants still have played significant role in their life. The pharmacological studies indicate the immense potential of medicinal plants in the treatment of various chronic and lethal diseases. Use of Asparagus racemosus as galactogogue, Berberis asiatica for eye troubles, Cordyceps sinensis as tonic and longetivity, Curculigo orchoides as tonic and aphrodisiac, Nardostachya grandiflora for epilepsy and Phyllanthus emblica as diuretic possessed the highest consensus factor and greater affinity to the Ayurveda and phytochemical findings. One of the factors constraining conservation, efficient use and sustainable management of medicinal plants and indigenous knowledge of utilization is the inability of users to recognize or commensurately value the functions and services of the products. Therefore similar research efforts on documentation and conservation of local plant resources and traditional knowledge are worthwhile.

\section{References:}

Bajracharya, M.B. 1979. Ayurvedic medicinal plant and general treatments. Jore Ganesh Press Pvt. Ltd, Kathmandu, Nepal. 230p.

Balansand, J. \& M. Rayband. 1987. Diuretic action of Asparagus officinalis. Critical Reviews in Society of Biology 126: 954-956.

Bandyopadhyay, S.K., S.C. Pakrashi \& A. Pakrashi. 2000. The role of antioxidant activity of Phyllanthus emblica fruits on prevention from indomethacin induced gastric ulcer. Journal of Ethnopharmacology 70:171-176.

Bhattarai, N.K. 1997. Biodiversity-people interface in Nepal. NWFP 11. Medicinal plants for forest conservation and health care. FAO \& UN Rome, Italy.

CECI. 2006. Traditional knowledge, resource availability and management practices of NTFPS/ MADP. Kathmandu: CECI.

Chen, P.-F., Lai, P.-F., Zhang, P., Chen, L.-L., 1996. Antineoplastic activity of Heiji (rhizome of Astilbe chinensis). China Journal of Chinese Materia Medica 21:302-303.

CIRRUS. 2008. Business review. CIRRUS Kathmadu and Herb and NTFPs Co-ordination Committee, Department of Plant Resources, Kathmandu, Nepal 
CSIR 1994. The useful plants of India. Council of Scientific \& Industrial Research, New Delhi, India 918p.

Devkota, R. amd S.B. Karmacharya. 2003. Documentation in indigenous knowledge of medicinal plants in Gwallek VDC, Baitadi district, Nepal. Botanica Orientalis 3:135143.

Dhuley, J.N. 1997. Effect of some Indian herbs on macrophage functions in ochratoxin A treated mice. Journal of Ethnopharmacology 58:15-20.

Farzami, B, D Ahmadvand, S Vardasbi, FJ Majin \& S Khaghani 2003. Induction of insulin secretion by a component of Urtica dioica leaf extract in perifused Islets of Langerhans and its in vivo effects in normal and streptozotocin diabetic rats. Journal of Ethnopharmacology 89:47-53.

Kamat, J.P., K.K. Boloor, T.P.A. Devasagayam \& S.R. Venkatachalam. 2000. Antioxidant properties of Asparagus racemosus against damage induced by $\gamma$-radiation in rat liver mitochondria. Journal of Ethnopharmacology 71:425-435.

Khanna, A.K., R. Chander \& N.K. Kapoor. 1991. Hypolipidaemic activity of Abana in rats. Fitoterapia 62:271-275.

Kirtikar, K.K. \& B.D. Basu. 1981. Indian Medicinal Plants. II ed. Lalit Mohan Publication, India, p. 2650.

Krey, A.K. and E.F. Hahn. 1969. Berberine: complex with DNA. Science 66:755-757.

Kumar, V.P., N.S. Chauhan, H. Padh and M. Rajani. 2006. Search for antibacterial and antifungal agents from selected Indian medicinal plants. Journal of Ethnopharmacology 107:182-188.

Kunwar, R.M. 2002. Some threatened medicinal and aromatic plants: status, trade and management practice in Dolpa district, mid-western Nepal. Journal of Natural History Museum 21:173-186.

Kunwar, R.M. 2006. Non-timber forest products of Nepal: a sustainable management approach. International Tropical Timber Organization, Japan and Center for Biological Conservation, Nepal. 423p.

Kunwar, R.M. 2007. Ecology and economy of Jaibik Jadibuti, Medicinal, aromatic and dye plants for sustainable livelihood project west Nepal; an assessment of initial and final level status and beneficiaries of the project. (Report) CECI, Kathmandu Nepal.

Kunwar, R.M., Y. Uperty, C. Burlakoti, C.L. Chowdhary and R.W. Bussmann. 2008. Indigenous use and ethnopharmacology of medicinal plants in far-west Nepal. Journal of Ethnobotany and Research Application Vol 6 available at www.ethnobotanyjournal.org.

Lebedev, A.A., Batakov, E.A., Kurkin, V.A., Lebedeva, E.A., Zapesochnaya, G.G., Avdeeva, E.V., Simonova, G.V., and A.V. Volotsueva. 2001. The antioxidative activity of a complex hepatoprotective preparation, silybokhol. Rastitel'nye Resursy 37:69-75.

Liu, C., Lu S. and M.R. Ji. 1992: Effects of Cordyceps sinensis (CS) on in vitro natural killer cells. Chung Kuo Chung His I Chieh Ho Tsa Chih 12:267-269.

Manandhar, N.P. 1998. Native Phytotherapy among the Raute tribes of Dadeldhura district, Nepal. Journal of Ethnopharmacology 60:199-206.

Moon, TC, XL Chang, JS Lee, DS Kim, K Bae, KH Son, HP Kim, SS Kang, JK Son and HW Chang. 2005. Antiinflammatory activity of astilbic acid from Astilbe chinensis. Biological and Pharmaceutical Bulletin 28: 24-26 
Mujumdar, A.M. and A.V. Misar. 2004. Anti-inflammatory activity of Jatropha curcas roots in mice and rats. Journal of Ethnopharmacology 90:11-15.

Nagpal, A. and M. Karki. 2004. A study on marketing opportunities for medicinal, aromatic and dye plants in South Asia. IDRC, Canada, 114p.

Pie Shengji, J. 2001. Ethnoecological approaches of traditional medicine studies: some experiences from Asia. Pharmacoceutical Biology 39:74-79.

Rao, V.S., A. Rao and K.S. Karanth. 2005. Anticonvulsant and neurotoxicity profile of Nardostachys jatamansi in rats. Journal of Ethnopharmacology 102:351-356.

Sabir, M. and M.K. Bhide. 1971. Study of some pharmacological activities of berberine. Ind J Physiol Pharm 15:111-132.

Sabnis, P.B., B.B. Gaitonde and M. Jetinalani. 1968. Effects of alcoholic extracts of Asparagus racemosus on mammary glands of rats. Indian Journal of Experimental Biology 6:55-57.

Sharma, S., S. Ramji, S. Kumari and J.S. Bapna. 1996. Randomized controlled trial of Asparagus racemosus (Shatavari) as a lactogogue in lactational inadequacy. Indian Pediatrics 32:675-677.

Subramonium, A. and P. Pushpangadan. 1999. Development of phytomedicines of liver diseases. Indian Journal of Pharmacology 31(3):166-175.

Taylor, R.S.L., F. Edel, N.P. Manandhar and G.H.N. Towers. 1996. Antimicrobial activities of southern Nepalese medicinal plants. Journal of Ethnopharmacology 50:97-102.

Testai, L, S Chericoni, V Calderone, G Nencioni, P Neiri, I Morelli and E Martinitti. 2002. Cardivascular effects of Urtica dioica root extracts: in vitro and in vivo pharmacological studies. Journal of Ethnopharmacology 81:105-109.

Trotter, R.T. and M.H. Logan. 1986. Informant consensus: a new approach for identifying potentially effective medicinal plants. Pp. 91-112. - In: Ektin N.L. (ed.): Plants in indigenous medicine and diet. Redgrave Pub. Co. Bedford Hill, New York.

Valls, J., T. Richard, F. Larronde, V. Leblais, B. Muller, J.C. Delaunay, J.P. Monti, K.G. Ramawat and J.M. Merillon. 2006. Two new benzyl benzonate glucosides from Curciligo orchoides. Fitoterapia 77:416-419.

Vermani, K. and S. Garg. 2002. Herbal medicines for sexually transmitted diseases and AIDS. Journal of Ethnopharmacology 80:49-66.

Wang, Sheng-Yuan and Shiao, Ming-Shi. 2000. "Pharmacological functions of Chinese medicinal fungus Cordyceps sinensis and related species". J. Food and Drug Analysis 8(4):248-257.

Wu, JY, QX Zhang and PO Leung. 2007. Inhibitory effect of ethyl acetate extract of Cordyceps sinensis mycelium on various cancer cells in culture and B16 melanoma in C57BL/6 mice. Phytomedicine 14:43-49.

Yadav, S. 2008. Popularly used medicinal plants by Tamang ethnic group at three VDCs of Rasuwa district, Central Nepal Himalaya. Master thesis, Central Department of Botany, Tribhuvan University, Kathmandu, Nepal. 75p.

Zhang, JP, Zhang M, Jin C, Zhou B, Xie WF, and Guo C. 2001. Matrine inhibits production and actions of fibrogenic cytokines released by mouse peritoneal macrophages. Acta Pharmacol Sin 22:765-8. 